\title{
Activity-based protein profiling of the hepatitis $C$ virus replication in Huh-7 hepatoma cells using a non-directed active site probe
}

\author{
Ragunath Singaravelu ${ }^{1,2+}$, David R Blais ${ }^{1 \dagger}$, Craig S McKay ${ }^{1,3}$, John Paul Pezacki ${ }^{1,2,3^{*}}$
}

\begin{abstract}
Background: Hepatitis $\mathrm{C}$ virus ( $\mathrm{HCV}$ ) poses a growing threat to global health as it often leads to serious liver diseases and is one of the primary causes for liver transplantation. Currently, no vaccines are available to prevent HCV infection and clinical treatments have limited success. Since HCV has a small proteome, it relies on many host cell proteins to complete its life cycle. In this study, we used a non-directed phenyl sulfonate ester probe (PS4झ) to selectively target a broad range of enzyme families that show differential activity during HCV replication in Huh-7 cells.

Results: The PS4三 probe successfully targeted 19 active proteins in nine distinct protein families, some that were predominantly labeled in situ compared to the in vitro labeled cell homogenate. Nine proteins revealed altered activity levels during HCV replication. Some candidates identified, such as heat shock 70 kDa protein 8 (or HSP70 cognate), have been shown to influence viral release and abundance of cellular lipid droplets. Other differentially active PS4 $\equiv$ targets, such as electron transfer flavoprotein alpha, protein disulfide isomerase A5, and nuclear distribution gene $\mathrm{C}$ homolog, constitute novel proteins that potentially mediate HCV propagation.

Conclusions: These findings demonstrate the practicality and versatility of non-directed activity-based protein profiling (ABPP) to complement directed methods and accelerate the discovery of altered protein activities associated with pathological states such as HCV replication. Collectively, these results highlight the ability of in situ ABPP approaches to facilitate the identification of enzymes that are either predominantly or exclusively labeled in living cells. Several of these differentially active enzymes represent possible HCV-host interactions that could be targeted for diagnostic or therapeutic purposes.
\end{abstract}

\section{Background}

The hepatitis $\mathrm{C}$ virus (HCV) is the major causative agent of hepatitis that affects over three percent of the global population [1]. With no vaccines yet available and clinical treatments that have only limited success, many HCV-infected individuals develop chronic hepatitis which eventually progresses into liver steatosis, cirrhosis and hepatocellular carcinoma. HCV is the leading cause of liver disease and transplantation [2]. As the $\mathrm{HCV}$ genome is a single-stranded RNA molecule of only $\sim 9.6 \mathrm{~kb}$ (Figure 1A) that encodes for ten mature viral proteins, HCV relies heavily on host factors for its

\footnotetext{
* Correspondence: John.Pezacki@nrc-cnrc.gc.ca

† Contributed equally

'Steacie Institute for Molecular Sciences, National Research Council Canada,
} Ottawa, Ontario, K1A OR6, Canada propagation. During cell entry, HCV E1 and E2 viral proteins interact with four known host receptors CD81, claudin-1, SRB1, and occludin [3]. Unpackaging is followed by the synthesis of the HCV polypeptide by host cell ribosomes that is subsequently processed into ten viral proteins by host cellular signal peptidase, signal peptide peptidase, and viral proteases NS2 and NS3/4A [4]. Host-mediated post-translational modifications, such as glycosylation of E1 and E2 [5], phosphorylation of NS5A [6], as well as the direct interaction with host cell geranylgeranylated FBL2 protein [7] and liver microRNA miR-122 [8,9], are also deemed essential for viral protein maturation and proper viral infectivity.

High throughput techniques, such as gene expression profiling and proteomic approaches have led to the identification of several host-viral interactions $[10,11]$. However,

\section{() Biomed Central}


some host cell factors involved in $\mathrm{HCV}$ propagation are likely regulated both by post-translational modifications and association with cofactors and regulatory proteins, for which conventional abundance-based genomic and proteomic techniques provide no direct information. Activitybased protein profiling (ABPP) was developed to provide a direct insight into changes in catalytic activity of enzyme classes in complex proteomes [12-14] and to annotate previously unknown enzymatic functions of proteins [15]. ABPP employs active site-directed covalent probes that consist of small molecule inhibitors linked to reporter tags [12] that exploit conserved mechanistic features of their target enzyme superfamily. Examples of ABPP probes includes fluorophosphonates, acyloxymethyl ketones, and amino acid coupled quinolimine methides that target serine hydrolases [16] and proteases $[17,18]$. We have previously applied some of these directed probes to study the differential activity of host cell proteases during $\mathrm{HCV}$ replication [19].

Although directed ABPP is effective for targeting enzymes with known covalent inhibitors, there is a lack of such cognate inhibitors for many enzyme classes. To extend the number of enzyme classes addressable by ABPP, non-directed probes were designed through the screening of large libraries of small molecule inhibitors against complex proteomes for activity-dependent protein reactivity [20,21]. Non-directed sulfonate ester [20], $\alpha$-chloroacetamide [22], and spiroepoxide [23] probes were successfully used to target a wider range of protein candidates through their reactivity with numerous enzyme families. Herein, we applied activity-based profiling using a non-directed phenyl sulfonate ester (PS4三) probe [20] to examine a wider range of enzyme families involved in $\mathrm{HCV}$ replication.

\section{Results and discussion}

\section{Characterization of non-directed activity based labeling}

Directed ABPP probes have successfully targeted over a dozen of different enzyme classes [24,25]. However, due to the lack of cognate affinity labels, numerous enzymes remain beyond the reach of directed ABPP. In this study, we investigated the ability of ABPP approaches using the non-directed PS4 $\equiv$ probe to profile enzyme activity in Huh-7 cells harboring the genotype $1 \mathrm{~b} \mathrm{HCV}$ subgenomic replicon RNA (Figure 1) [26,27]. The selection of the PS4三 probe was based on its activity-based reactivity towards a large but manageable fraction of the proteome (over half a dozen distinct enzyme families are known to be targeted) $[21,28]$ and on its relatively small size, which should minimize non-covalent probeprotein interactions and allow cellular uptake and distribution for in situ labeling.

To achieve in-gel fluorescence detection of the labeled protein candidates, a rhodamine dye was coupled to an azide group for a subsequent conjugation via Huisgen's 1,3-dipolar cycloaddition ('click' chemistry) with the alkyne group on the probe (Figure $1 \mathrm{C}$ ). The configuration of both bioorthogonal coupling partners, the alkyne on PS4 $\equiv$ and the azide on the rhodamine reporter $\left(\mathrm{RhN}_{3}\right)$, was chosen over the reverse position of functional groups of the cycloaddition reaction (i.e. $\mathrm{PSN}_{3}$ and $\mathrm{Rh} \equiv)$ as the first configuration proved to significantly minimize non-specific labeling of abundant proteins [28] (Figure 2).

The PS4 $\equiv$ probe specificity was determined in vitro with the isolated proteome of Huh-7 cells resuspended in sodium phosphate buffer, for which the optimal labeling condition was observed to be $20 \mu \mathrm{M}$ for one hour at $37^{\circ} \mathrm{C}$ (Figure 2A). At this concentration, the heat denatured proteome revealed minimal non-specific reactivity while displaying maximal sensitivity (Figures 2A, 3A-C). At first glance, the PS4 $\equiv$ probe had a unique fluorescence labeling profile (Figure 3) when compared with amino acid coupled quinolimine methide probes in Huh-7 cells [19]. Five spots (Figure 3G, \#1, 2, 3, 4, 9), comprising isomerases and chaperones (Table 1), displayed a significant differential activity in vitro between naïve Huh-7 cells and those stably replicating HCV, highlighting the importance of the PS4 $\equiv$ non-specific probe to complement directed ABPP for providing a broader assessment of the differentially active proteome between control cells and cells replicating HCV RNA.

\section{In situ PS4 $\equiv$ labeling increases the number of ABPP hits}

An additional advantage of the PS4 $\equiv$ probe is conferred by its small molecular size for in situ ABPP. This, in turn, allows the labeling of active enzymes in their native subcellular environment to provide the most physiologically relevant enzymatic profile. The in situ conditions were optimized by varying the PS4三 concentration in the cellular media to obtain a fluorograph of similar banding pattern, fluorescence intensity, and minimal background as to the in vitro labeling. Under normalized labeling conditions (in situ labeling for 1 hour with $100 \mu \mathrm{M}$ in cell culture media; in vitro labeling for 1 hour with 20 $\mu \mathrm{M}$ probe in $1 \mathrm{mg} / \mathrm{mL}$ soluble proteome), the in situ fluorescent labeling profile in Huh-7 cells (Figure 4) was found quantitatively comparable to the in vitro profile (Figure 3), as judged by the fluorescent spot intensity of both profiles (Figure $4 \mathrm{E}$ ) and taking into consideration the silver stained gels as loading controls (Figures $3 \mathrm{D}-\mathrm{F}$ and $4 \mathrm{C}-\mathrm{D}, 200 \mu \mathrm{g}$ of proteome loaded per gel). The increased concentration of PS4 $\equiv$ required for in situ labeling could be attributed to cellular uptake as the probe is thought to enter the cell via passive diffusion.

Although some of the proteins were labeled equally in vitro and in situ, the latter resulted in some proteins that were predominantly labeled in situ when compared to the 
A

HCV genome 5'-UTR \begin{tabular}{|l|l|l|l|l|l|l|l|l|l|}
\hline C & E1 & E2 & P7 & NS2 & NS3 & 4A & 4B & NS5A & NS5B \\
\hline
\end{tabular}

pFK-I389neo/NS3-3'/5.1

bi-cistronic replicon

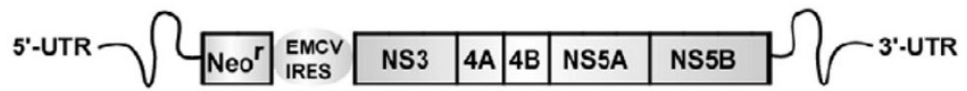

B

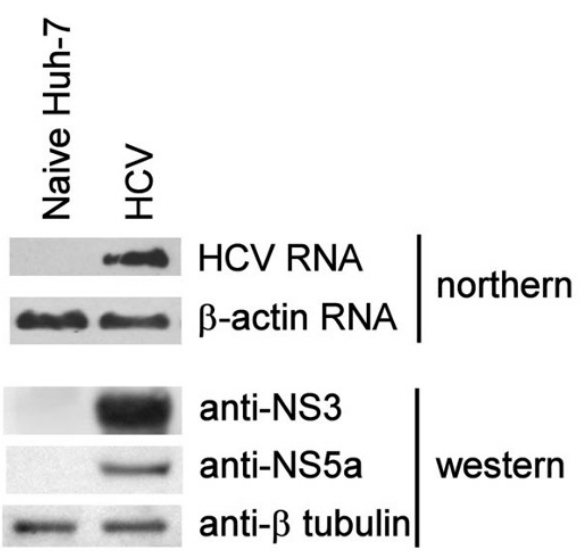

C

Active

liver proteome

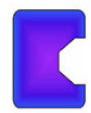
$\checkmark$

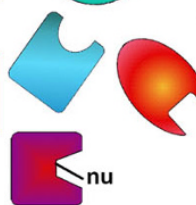

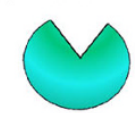

In vitro or in situ activity labeling

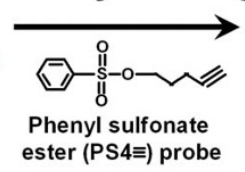

PS4 = labeled proteome
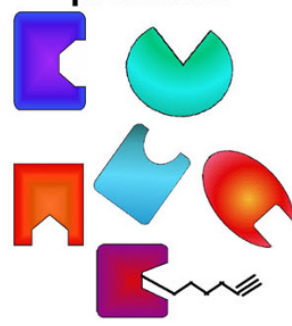

Huisgen's 1,3-dipolar cycloaddition

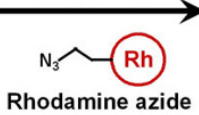
$\left(\mathrm{RhN}_{3}\right)$

\section{Fluorescent labeled proteome}
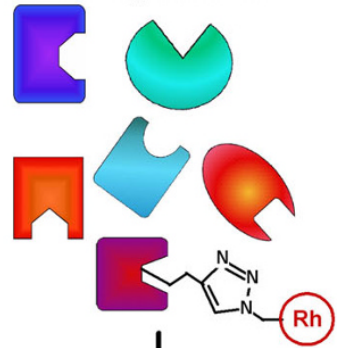

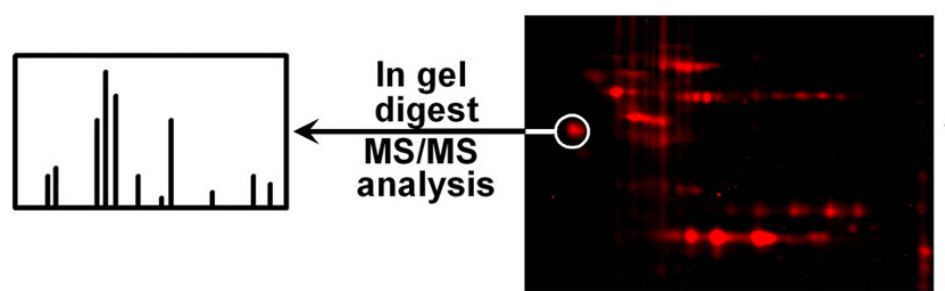

2D gel electrophoresis

Figure 1 Structure and protocol of the PS4三 probe used in vitro and in situ to target the active Huh-7 proteome during HCV replication. (A) Schematic representations of the HCV genome and the bi-cistronic (pFK-1389neo/NS3-3'/5.1) subgenomic replicon used in this study (NS, non-structural proteins). (B) Northern analysis of HCV and $\beta$-actin (as a loading control) RNA (upper two blots) and detection of HCV NS3, HCV NS5A, and $\beta$-tubulin (as a loading control) proteins by western blotting (lower three blots) in naïve Huh-7 human hepatoma cell lines and in Huh-7 cells stably replicating HCV (HCV). (C) Scheme of the ABPP protocol used to identify phenyl sulfonate ester (PS4三) targets. The active proteome of naïve Huh-7 cells (not shown) or Huh-7 stably expressing the HCV replicon was labeled through a nucleophilic (Nu) residue within the active site of the enzyme targeted by the reactive group of the PS4三 probe. After isolation, the labeled proteome was conjugated with the rhodamine azide reporter tag $\left(\mathrm{RhN}_{3}\right)$ via the Huisgen's 1,3-dipolar cycloaddition and separated by two-dimensional gel electrophoresis. The fluorescently tagged proteins were identified by LC-MS/MS. 


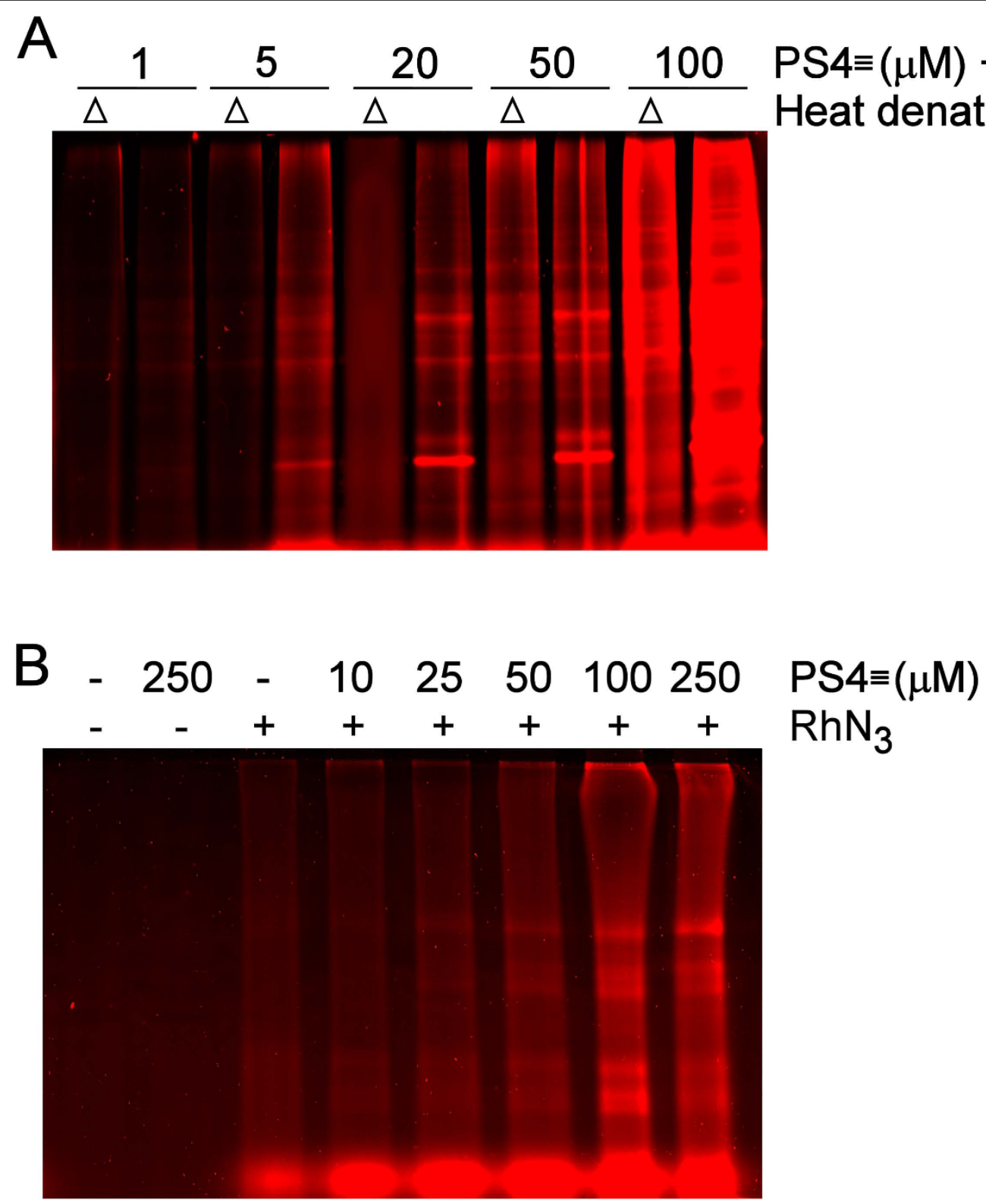

Figure 2 In vitro and in situ PS4三 probe condition optimization for labeling the active proteomes from Huh-7 cells. (A) Active proteomes isolated from naïve Huh-7 cells were treated at $37^{\circ} \mathrm{C}$ for 60 min with various concentrations of substrate based probes (PS4三) either with or without a denaturing preheating step $\left(\Delta=100^{\circ} \mathrm{C}, 5 \mathrm{~min}\right)$, subjected to click chemistry with $\mathrm{RhN}_{3}$, separated by SDS/PAGE

electrophoresis, and visualize by in-gel fluorescence scanning. The in vitro optimal PS4三 concentration with the strongest signal from the active proteome and least non-specific binding from the denatured proteome was determined to be $20 \mu \mathrm{M}$. (B) In situ optimal labeling conditions for the naïve Huh-7 proteome to give the strong and similar banding patterns as experiments conducted in vitro was determined to be an hour incubation of $100 \mu \mathrm{M}$ of PS4三 probe in cell culture media. Non-specific fluorescence was observed to be negligible when either the PS4三 probe or $\mathrm{RhN}_{3}$ was omitted.

cell homogenate (Figure 4E, spots \# 2, 3, 4, 6, 7, 8, 10, 11, 18 and 19), which validates previous observations [28]. These enzymes included: a chaperone (heat shock protein 70 ), one isomerase (protein disulfide isomerase A1), two ion-binding proteins (alpha 2-HS-glycoprotein and nucleobindin), one electron transport protein (electron transfer flavoprotein alpha), one hydrolase (ATP synthase beta), and two transferases (quinolinate phosphoribosyltransferase and purine nucleoside phosphorylase) (Table 1). The decreased in vitro labeling of some proteins may be attributed to the homogenate obtained by physical disruption of the Huh-7 cells for in vitro ABPP, altering the concentration and subcellular distribution of endogenous inhibitors/activators and protein-protein interactions 


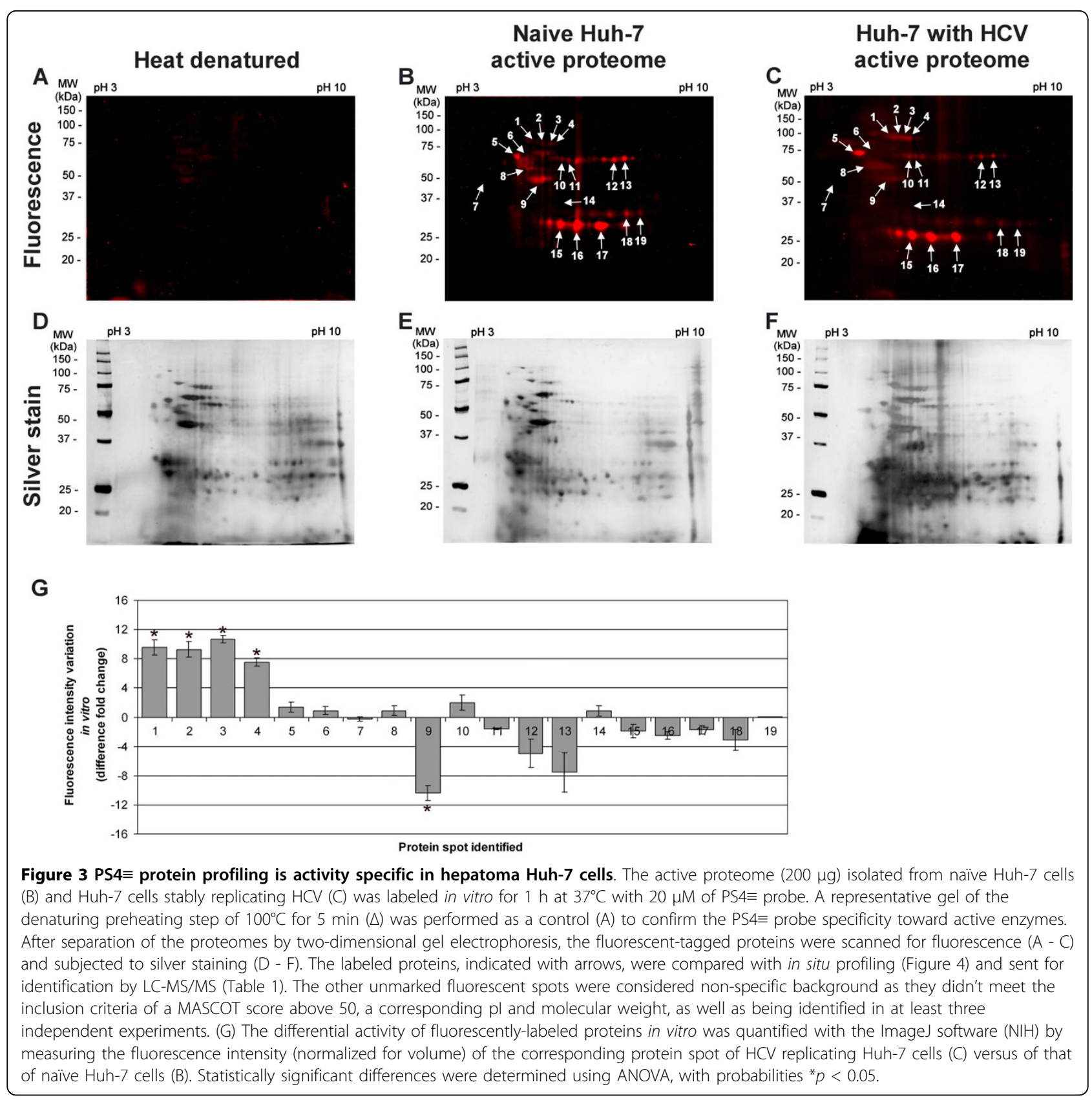

needed for enzymatic activity [29]. Such physiologically disruptive effects would explain the significant reduction in ABPP labeling in vitro for ATP synthase beta (Figure $4 \mathrm{E}$, spot 8 ); moreover, membrane disruption through proteome isolation likely resulted in the loss of the proton gradient needed for the conformational change of the $\beta$ subunits of the transmembrane enzyme. This would prevent the subsequent release of the ATP product and significantly abolishing the enzyme's hydrolase activity [30]. The enhanced labeling of some protein targets in situ could also be attributed to the uneven subcellular distribution of the probe taken by cells, which could lead to the enrichment of the probe in certain cellular organelles and disproportionately enhance protein labeling [28]. However, this enrichment would be expected to be consistent and not a significant variable factor among in situ samples analyzed simultaneously (i.e. Figure 4A-B) making the PS4三 probe suitable for interrogating enzyme activity in their native cellular environment.

\section{Identification of labeled polypeptides in Huh-7 cells}

To identify the enzymes labeled by the PS4三 probe, the combination of fluorescence 2D-gel electrophoresis (2D$\mathrm{GE}$ ) and tandem mass spectrometry was used as 
Table 1 Identification of labeled proteins with the PS probe from Figures 3 and 4.

\begin{tabular}{|c|c|c|c|c|c|c|c|c|}
\hline $\begin{array}{c}\text { Gel } \\
\text { band* }\end{array}$ & Protein & Function & $\begin{array}{l}\text { Accession } \\
\text { no. (NCBI) }\end{array}$ & $\begin{array}{l}\text { Mass } \\
(\mathrm{kDa})\end{array}$ & $\mathrm{pl}$ & $\begin{array}{l}\text { MASCOT } \\
\text { score*** }\end{array}$ & $\begin{array}{c}\text { Sequence } \\
\text { coverage } \\
(\%)\end{array}$ & Peptide sequence \\
\hline 1 & $\begin{array}{c}\text { Protein disulfide isomerase- } \\
\text { associated } 4\end{array}$ & Isomerase & 4758304 & 72.89 & 4.96 & 57 & 3.4 & $\begin{array}{l}\text {-FDVSGYPTIK } \\
\text {-IDATSASVLASR }\end{array}$ \\
\hline 2 & Heat shock $70 \mathrm{kDa}$ protein 5 & Chaperone & 16507237 & 72.29 & 5.07 & 929 & 36.2 & $\begin{array}{l}\text {-VMEHFIK } \\
\text {-VLEDSDLK } \\
\text {-LTPEEIER } \\
\text {-ITITNDQNR } \\
\text {-DAGTIAGLNVMR } \\
\text {-VEIIANDQGNR } \\
\text {-DAGTIAGLNVMR + Ox. of M } \\
\text {-FEELNMDLFR } \\
\text {-NELESYAYSLK } \\
\text {-ELEEIVQPIISK } \\
\text {-TWNDPSVQQIK } \\
\text {-SDIDEIVLVGGSTR } \\
\text {-TFAPEEISAMVLTK } \\
\text {-TFAPEEISAMVLTK + Ox. of } \\
\text { M } \\
\text {-ITPSYVAFTPEGER } \\
\text {-IINEPTAAAIAYGLDK } \\
\text {-NQLTSNPENTVFDAK } \\
\text {-SQIFSTASDNQPTVTIK } \\
\text {-LYGSAGPPPTGEEDTAEKDEL }\end{array}$ \\
\hline 3 & $\begin{array}{c}\text { Heat shock } 70 \mathrm{kDa} \text { protein } 8 \\
\text { isoform } 1\end{array}$ & Chaperone & 5729877 & 70.85 & 5.37 & 767 & 32.5 & $\begin{array}{l}\text {-ITITNDK } \\
\text {-LSKEDIER } \\
\text {-FELTGIPPAPR } \\
\text {-DAGTIAGLNVLR } \\
\text {-VEIIANDQGNR } \\
\text {-YKAEDDLQR } \\
\text {-MVNHFIAEFK } \\
\text {-FEELNADLFR } \\
\text {-NSLESYAFNMK + Ox. of M } \\
\text {-SQIHDIVLVGGSTR } \\
\text {-TPSYVAFTDTER } \\
\text {-SFYPEEVSSMVLTK } \\
\text {-NQVAMNPTNTVFDAK } \\
\text {-IINEPTAAAIAYGLDK } \\
\text {-NQVAMNPTNTVFDAK + Ox. } \\
\text { Of M } \\
\text {-STAGDTHLGGEDFDNR } \\
\text {-TVTNAWTVPAYFNDSQR }\end{array}$ \\
\hline 4 & Heat shock $70 \mathrm{kDa}$ protein 9 & Chaperone & 12653415 & 73.68 & 6.03 & 665 & 22.2 & $\begin{array}{l}\text {-VLENAEGAR } \\
\text {-RYDDPEVQK } \\
\text {-QAASSLQQASLK } \\
\text {-DAGQISGLNVLR } \\
\text {-VQQTVQDLFGR } \\
\text {-AQFEGIVTDLIR } \\
\text {-SDIGEVILVGGMTR } \\
\text {-TTPSWAFTADGER } \\
\text {-LYSPSQIGAFVLMK } \\
\text {-QAVTNPNNTFYATK } \\
\text {-LLGQFTLIGIPPAPR } \\
\text {-NAVITVPAYFNDSQR }\end{array}$ \\
\hline
\end{tabular}


Table 1: Identification of labeled proteins with the PS probe from Figures 3 and 4. (Continued)

\begin{tabular}{|c|c|c|c|c|c|c|c|c|}
\hline $\begin{array}{c}\text { Gel } \\
\text { band* }\end{array}$ & Protein & Function & $\begin{array}{l}\text { Accession } \\
\text { no. (NCBI) }\end{array}$ & $\begin{array}{l}\text { Mass } \\
(\mathrm{kDa})\end{array}$ & $\mathrm{pl}$ & $\begin{array}{l}\text { MASCOT } \\
\text { score }^{* *}\end{array}$ & $\begin{array}{l}\text { Sequence } \\
\text { coverage } \\
(\%)\end{array}$ & Peptide sequence \\
\hline 5 & Vimentin & $\begin{array}{l}\text { Structural, } \\
\text { filament }\end{array}$ & 340219 & 53.68 & 5.03 & 487 & 24.5 & $\begin{array}{l}\text {-QVDQLTNDK } \\
\text {-DNLAEDIMR } \\
\text {-QDVDNASLAR } \\
\text {-FADLSEAANR } \\
\text {-VELQELNDR } \\
\text {-EYQDLLNVK } \\
\text {-ILLAELEQLK } \\
\text {-LGDLYEEEMR } \\
\text {-NLQEAEEWYK } \\
\text {-SLYASSPGGYATR } \\
\text {-ISLPLPNFSSLNLR }\end{array}$ \\
\hline 6 & $\begin{array}{c}\text { Prolyl 4-hydroxylase, beta subunit } \\
\text { precursor (Protein disulfide } \\
\text { isomerase) }\end{array}$ & $\begin{array}{l}\text { Isomerase } \\
\text { (chaperone) }\end{array}$ & 20070125 & 57.08 & 4.76 & 619 & 28.5 & $\begin{array}{l}\text { - FFPASADR } \\
\text { - QLAPIWDK } \\
\text { - ENLLDFIK } \\
\text { - LKAEGSEIR } \\
\text { - VHSFPTLK } \\
\text { - ILEFFGLK } \\
\text { - THILLFLPK } \\
\text { - EADDIVNWLK } \\
\text { - LITLEEEMTK } \\
\text { - NFEDVAFDEK } \\
\text { - MDSTANEVEAVK + Ox. of } \\
\text { M } \\
\text { - YQLDKDGWLFK } \\
\text { - VDATEESDLAQQYGVR } \\
\text { - HNQLPLVIEFTEQTAPK }\end{array}$ \\
\hline 7 & Alpha 2-HS-glycoprotein & lon binding & 156523970 & 39.33 & 5.43 & 136 & 6.3 & $\begin{array}{l}\text {-HTLNQIDEVK } \\
\text {-CDSSPDSAEDVRK }\end{array}$ \\
\hline 8 & ATP synthase beta subunit & Hydrolase & 1374715 & 51.17 & 4.92 & 541 & 32.6 & $\begin{array}{l}\text {-IGLFGGAGVGK } \\
\text {-IPVGPETLGR } \\
\text {-WDLLAPYAK } \\
\text {-TIAMDGTEGLVR } \\
\text {-TIAMDGTEGLVR + Ox. of M } \\
\text {-IMNVIGEPIDER } \\
\text {-IMNVIGEPIDER + Ox. of M } \\
\text {-FTQAGSEVSALLGR } \\
\text {-TVLIMELINNVAK } \\
\text {-VALVYGQMNEPPGAR } \\
\text {-VALVYGQMNEPPGAR + Ox. } \\
\text { of M } \\
\text {-AIAELGIYPAVDPLDSTSR }\end{array}$ \\
\hline 9 & Protein disulfide isomerase A5 & Isomerase & 1710248 & 46.17 & 4.95 & 357 & 15.6 & $\begin{array}{l}\text {-AATALKDWK } \\
\text {-GESPVDYDGGR } \\
\text {-TGEAIVDAALSALR } \\
\text {-NLEPEWAAAASEVK } \\
\text {-LAAVDATVNQVLASR } \\
\text {-GSTAPVGGGAFPTIVER }\end{array}$ \\
\hline 10 & $\begin{array}{l}\text { Quinolinate phosphoribosyl- } \\
\text { transferase }\end{array}$ & Transferase & 13477197 & 30.81 & 5.82 & 109 & 11.4 & $\begin{array}{l}- \text { YDLGGLVMVK } \\
\text {-DNHWAAGGVEK } \\
\text {-YGLLVGGAASHR }\end{array}$ \\
\hline 11 & Nucleobindin & Ion binding & 189308 & 53.70 & 5.15 & 62 & 2.8 & -LVTLEEFLASTQR \\
\hline 12 & Phosphoglycerate dehydrogenase & Oxidoreductase & 5771523 & 56.63 & 6.29 & 196 & 10.5 & $\begin{array}{l}\text { - TLGILGLGR } \\
\text { - GGIVDEGALLR } \\
\text { - VTADVINAAEK } \\
\text { - ILQDGGLQWEK } \\
\text { - GTIQVITQGTSLK }\end{array}$ \\
\hline
\end{tabular}


Table 1: Identification of labeled proteins with the PS probe from Figures 3 and 4. (Continued)

\begin{tabular}{|c|c|c|c|c|c|c|c|c|}
\hline $\begin{array}{c}\text { Gel } \\
\text { band* }\end{array}$ & Protein & Function & $\begin{array}{l}\text { Accession } \\
\text { no. (NCBI) }\end{array}$ & $\begin{array}{l}\text { Mass } \\
(\mathrm{kDa})\end{array}$ & $\mathrm{pl}$ & $\begin{array}{l}\text { MASCOT } \\
\text { score }^{* *}\end{array}$ & $\begin{array}{l}\text { Sequence } \\
\text { coverage } \\
(\%)\end{array}$ & Peptide sequence \\
\hline 13 & Aldehyde dehydrogenase 1 & Oxidoreductase & 2183299 & 54.80 & 6.30 & 293 & 11.0 & $\begin{array}{l}\text { - ILDLIESGK } \\
\text { - VAFTGSTEVGK } \\
\text { - QAFQIGSPWR } \\
\text { - EEIFGPVQQIMK + oxid(M) } \\
\text { - IFVEESIYDEFVR }\end{array}$ \\
\hline 14 & $\begin{array}{c}\text { Nuclear distribution gene } \mathrm{C} \\
\text { homolog }\end{array}$ & Protein binding & 5729953 & 38.22 & 5.27 & 87 & 6.0 & $\begin{array}{l}\text {-SETSGPQIK } \\
\text {-LVSSDPEINTK }\end{array}$ \\
\hline 15 & Cytokine induced protein $29 \mathrm{kDa}$ & $\begin{array}{c}\text { Nucleotide, } \\
\text { protein binding }\end{array}$ & 32129199 & 23.66 & 6.10 & 66 & 9.0 & $\begin{array}{l}\text {-FGISSVPTK } \\
\text {-ITSEIPQTER }\end{array}$ \\
\hline 16 & $\begin{array}{c}\text { Endoplasmic reticulum protein } 29 \\
\text { isoform } 1\end{array}$ & Chaperone & 5803013 & 28.97 & 6.77 & 269 & 25.7 & $\begin{array}{l}\text { - QGQDNLSSVK } \\
\text { - SLNILTAFQK } \\
\text { - FDTQYPYGEK } \\
\text { - ESYPVFYLFR } \\
\text { - GALPLDTVTFYK } \\
\text { - DGDFENPVPYTGAVK }\end{array}$ \\
\hline 17 & Proteasome subunit alpha type- 1 & Hydrolase & 190447 & 30.21 & 6.51 & 143 & 10.6 & $\begin{array}{l}\text {-LVSLIGSK } \\
\text {-ILHVDNHIGISIAGLTADAR }\end{array}$ \\
\hline 18 & Purine nucleoside phosphorylase & Transferase & 230387 & 32.13 & 6.45 & 84 & 9.7 & $\begin{array}{l}\text {-FEVGDIMLIR } \\
\text {-LGADAVGMSTVPEVIVAR }\end{array}$ \\
\hline 19 & $\begin{array}{l}\text { Electron transfer flavoprotein, } \\
\text { alpha polypeptide }\end{array}$ & $\begin{array}{l}\text { Electron } \\
\text { transport }\end{array}$ & 4503607 & 35.06 & 8.62 & 156 & 16.5 & $\begin{array}{l}\text {-SPDTFVR } \\
\text {-LEVAPISDIIAIK } \\
\text {-GLLPEELTPLILATQK } \\
\text {-AAVDAGFVPNDMQVGQTGK }\end{array}$ \\
\hline
\end{tabular}

* PS4 $\equiv$ probe labeled protein bands numbered in Figures 3 and 4.

** MASCOT minimal protein score $=50$.

outlined in Figure 1C. Fluorescence 2D-GE was chosen over multidimensional protein identification technology (MudPIT) for its high throughput quantitative analysis and topological protein information, in spite of lower protein detection and higher signal overlap from comigrating background proteins, which are two potential limiting factors for 2D-GE [14].

In vitro and in situ ABPP of the active proteome from naïve Huh-7 cells and cells stably replicating HCV, analyzed by $2 \mathrm{D}-\mathrm{GE}$ and LC-MS/MS, revealed 19 reactive candidates whose labeling were abolished when subjected to in vitro pre-denaturation step $(\Delta)$ at $100^{\circ} \mathrm{C}$ for 5 min (Figure 3). These candidates were considered positive hits, providing that they had a MASCOT score above 50, a corresponding $\mathrm{pI}$ and mass during 2D-GE migration, and reproducible identification in at least three independent experiments (Table 1). Due to the lack of eligibility criteria or reproducible identification, the other unmarked fluorescent spots were considered as non-specific background or co-migrating contaminants and were not further analyzed (data not shown).

Aside from the pre-denaturation step (Figure 2A, 3A), the activity dependent PS4= labeling is supported by the presence of known phenyl sulfonate targets in the reactive candidates, such as aldehyde dehydrogenase 1, for which the labeling has been shown to be blocked by the inhibitor disulfiram [28] and the cofactor $\mathrm{NAD}^{+}$[21], which suggests activity-dependent probe reactivity and cofactor-binding selectivity of targeted enzymes. Furthermore, mass spectroscopy analyses confirmed the binding of the PS4 $\equiv$ probe to the catalytic pocket of the enzymes. Mutations of those catalytic residues abolished more than $90 \%$ the PS4 $\equiv$ labeling compared to their wild-type counterpart [27]. In a catalytic assay, the probe (i.e. irreversible inhibitor)-bound wild-type targeted enzyme demonstrated more than a $90 \%$ reduction in activity toward its endogenous substrate [27]. These inhibition-based experiments validate the active-state specificity of the PS4三 probe labeling toward its protein targets.

\section{Characterization of the PS4 $\equiv$ probe targets}

The 19 PS4 $\equiv$ probe targets were grouped into their respective protein families (Table 1 , Figure 5A) where the majority of the candidates corresponded to enzyme classes previously labeled with phenyl sulfonate ester probes, including hydrolases, transferases, oxidoreductases, and isomerases $[20,21,27,28,31]$. Some of our Huh-7 PS4 $\equiv$ hits were previously identified with phenyl sulfonate probes in human breast cancer cells and in vivo mouse models, such as aldehyde dehydrogenase 1 $[20,27,28,32]$ and protein disulfide isomerase (i.e. prolyl 4-hydroxylase) [28], thereby validating our non-directed ABPP methodology in human hepatoma cells. The 


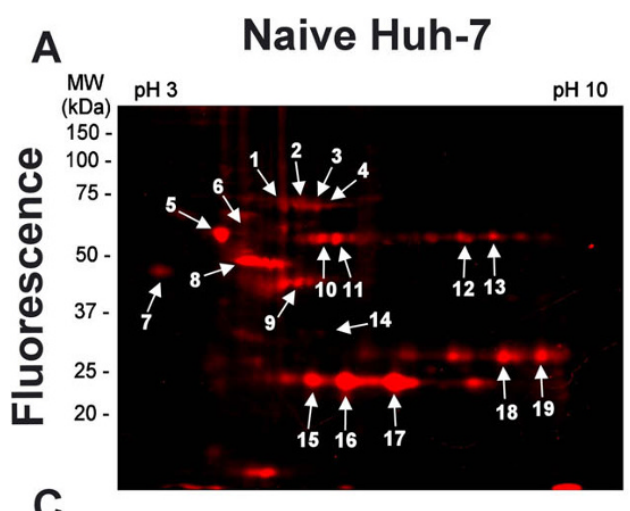

C

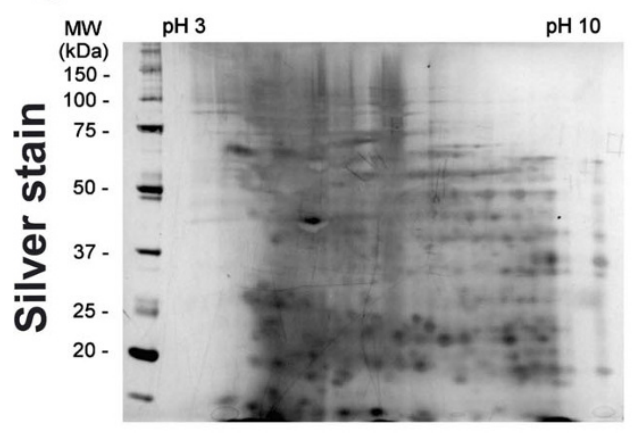

B

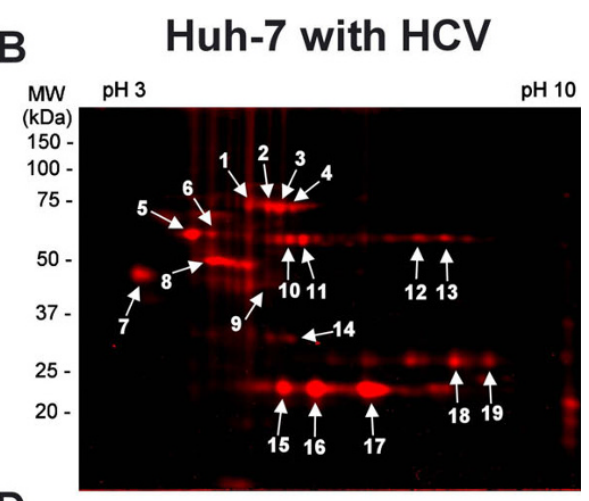

D

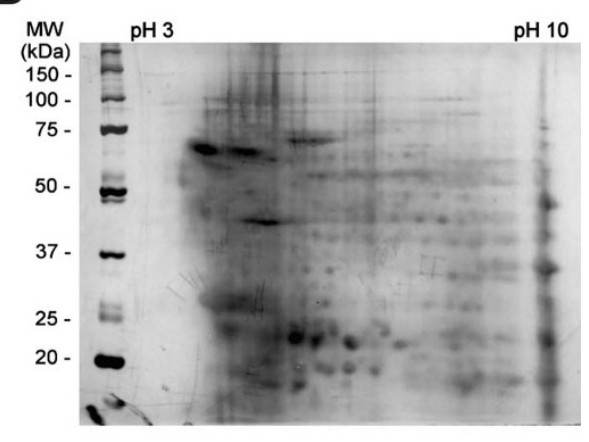

$\mathbf{E}$

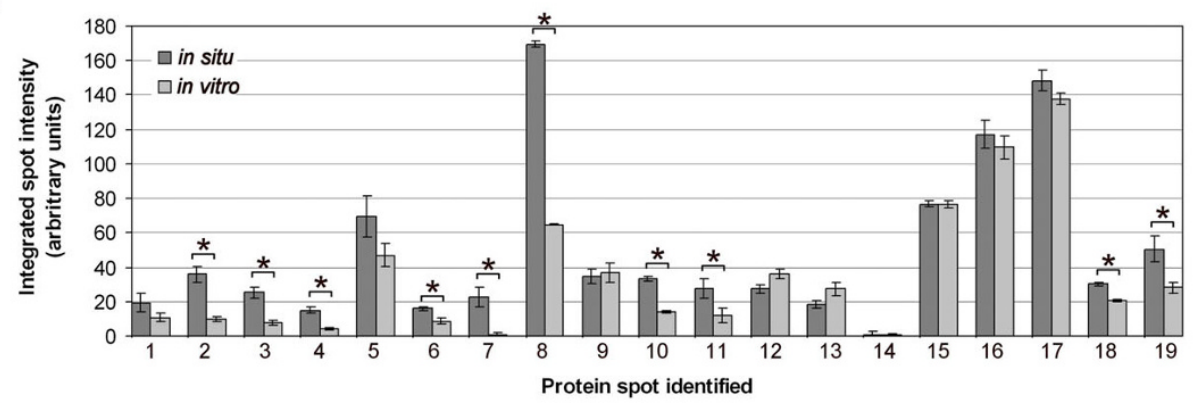

$\mathbf{F}$

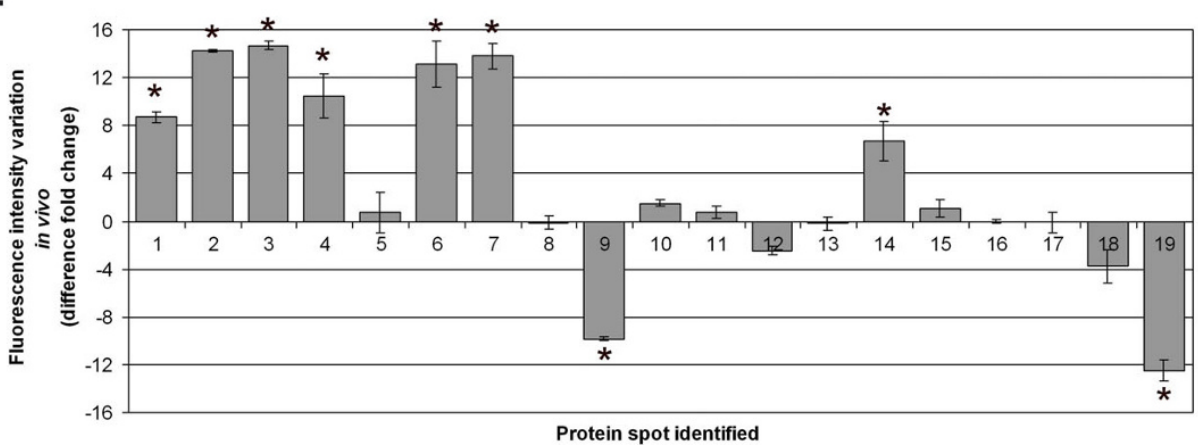

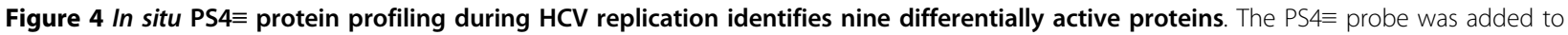
the cellular media of naïve Huh-7 cells (A) or Huh-7 stably expressing the HCV replicon (B) for $1 \mathrm{~h}$ at $37^{\circ} \mathrm{C}$. The labeled proteome was isolated and subjected to Huisgen's 1,3-dipolar cycloaddition with rhodamine azide. After separation of the proteomes by two-dimensional gel electrophoresis, the fluorescently tagged proteins were scanned (A, B), silver stained (C, D), and identified by LC-MS/MS (Table 1). (E) The differential activity between in situ (Figure 4) and in vitro (Figure 3) fluorescently labeled proteins in Huh-7 cells was quantified with the ImageJ software $(\mathrm{NIH})$ by measuring the fluorescence intensity (normalized for volume) of the corresponding protein spot. (F) The differential activity of fluorescently labeled proteins between HCV and naive Huh-7 cells was quantified with the ImageJ software (NIH) by measuring the fluorescence intensity (normalized for volume) of the corresponding protein spot of HCV replicating Huh-7 cells (B) versus of that of naïve Huh-7 cells (A). Statistically significant differences were determined using ANOVA, with probabilities ${ }^{*} p<0.05$. 
remaining candidates represent novel PS4三 targets (Table 1 ). The variety of the PS4 $\equiv$ hits (nine protein classes were identified in this study) (Figure 5A) could be reflected by the diversity of amino acids known to be labeled by the PS4三 probe (aspartate, cysteine, glutamate, and tyrosine) [27], which reveal the versatility of the phenyl sulfonate reactive group in labeling a diversity of catalytic residues in a range of mechanistically distinct enzymes. Some proteins targeted in Huh-7 cells were shown to utilize these amino acids as catalytic residues in their active pocket. For example, protein disulfide isomerases (spots 1, 6 and 9) have cysteine catalytic residues [33] whereas phosphoglycerate dehydrogenase (spot 12), aldehyde dehydrogenase 1 (spot 13), and purine nucleoside phosphorylase (spot 18) possess a catalytic glutamate [34-36]. Both types of residues would likely be covalently labeled by the PS4 $\equiv$ probe [27]. Alternatively, several previously PS4三 labeled enzymes were shown not to utilize covalent catalysis [20,31], thus suggesting a second labeling mechanism where a noncatalytic residue (such as cysteine) in the active pocket of non-enzymatic hits could serve as the site of labeling by the PS4 $\equiv$ probe [21]. The diversity of potential activity-based labeling mechanisms of the PS4 $\equiv$ probe could explain the broad range of proteins identified in Huh-7 cells (Table 1, Figure 5A).

\section{In situ PS4 $\equiv$ activity profiling during HCV replication}

To assess the non-directed activity profile during $\mathrm{HCV}$ replication, PS4三 profiling was performed on naïve Huh-7 cells and those stably replicating the pFKI389neo/NS3-3'/5.1 subgenomic HCV replicon [26,37-42] at high levels [19]. Several PS4 $\equiv$ targets (Table 1), including aldehyde dehydrogenase 1 , protein disulfide isomerase, phosphoglycerate dehydrogenase, heat shock protein $70 \mathrm{kDa}$ protein 5 , ATP synthase beta subunit, and endoplasmic reticulum protein 29 , were also detected with amino acid coupled quinolimine methide probes, confirming our previous findings [19] and supporting the concept that non-directed ABPP complements directed ABPP analysis through parallel [19] or multiplexed experiments [20]. Interestingly, $\mathrm{HCV}$ NS3/4A enzyme was not detected by the PS4三 probe, even in vivo. Labeling experiments using a fluorophosphonate and several substrate-based ABPP probes on purified recombinant $\mathrm{HCV}$ NS3/4A showed reluctance of the enzyme towards ABPP labeling [19]. This lack of detection could be attributed to several factors, including the low abundance of NS3/4A relative to

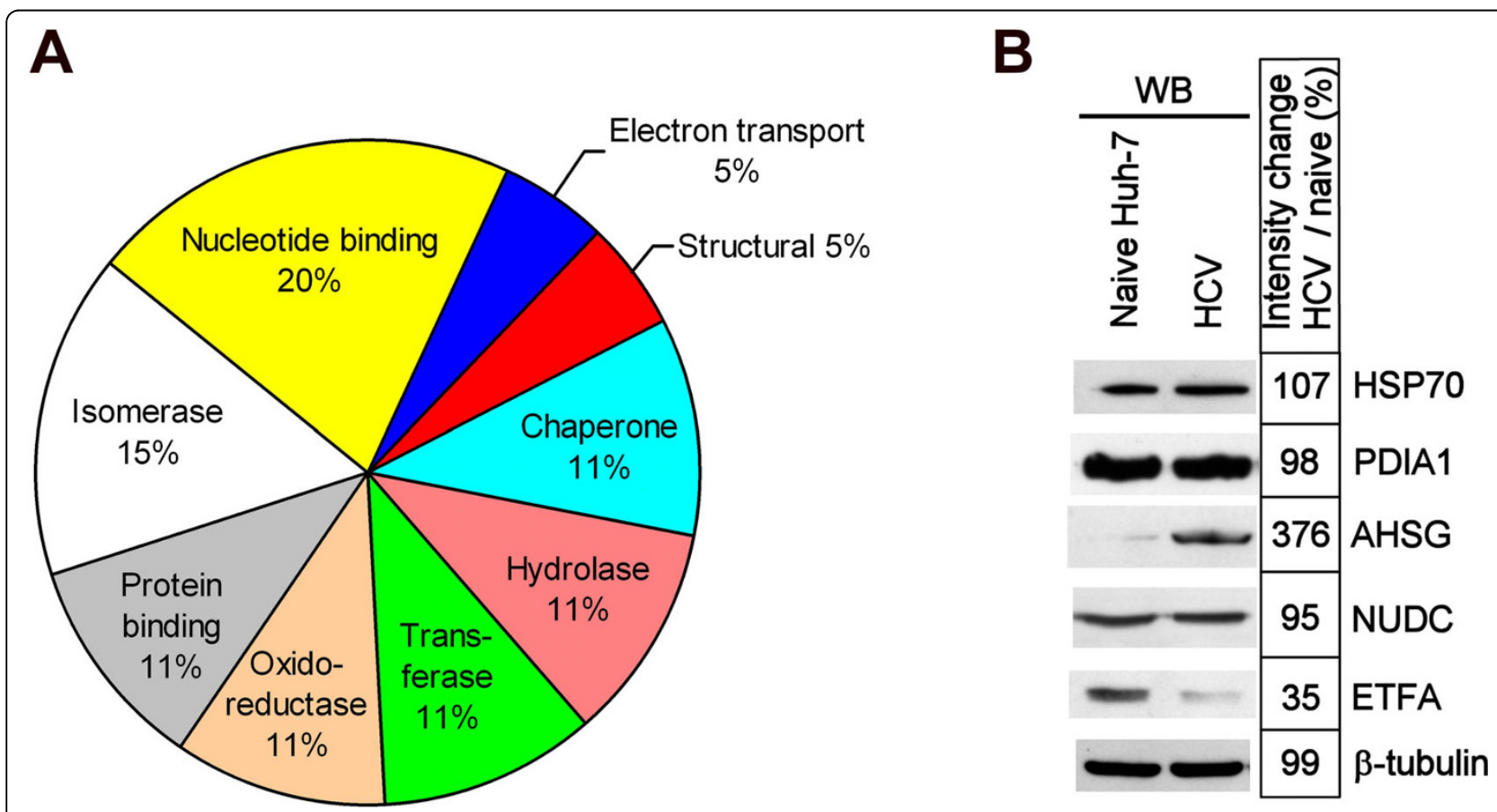

Figure 5 PS4 $\equiv$ non-directed activity-based profiling targets several protein classes during HCV replication. (A) Compilation of the 19 true probe targets from Figures 3 and 4 and classification into their corresponding protein family (data from Table 1). (B) Expression analysis of five differentially active protein candidates: heat shock protein 70 kDa (HSP70), protein disulfide isomerase A1 (PDIA1), alpha 2-HS-glycoprotein (AHSG), nuclear distribution gene C homolog (NUDC), and electron transfer flavoprotein alpha polypeptide (ETFA) (Figure 4 and Table 1). The expression analysis was performed by western blotting in the naïve Huh-7 cell line and Huh-7 stably expressing the bi-cistronic pFK-1389neo/ NS3-3'/5.1 subgenomic replicon (HCV). 
other host cell hydrolase or product inhibition of the enzyme [43].

Although heat shock $70 \mathrm{kDa}$ protein 5 was also labeled by both the PS4 $\equiv$ and amino acid coupled quinolimine methide probes in vitro [19], its activity was significantly higher during HCV replication in situ when compared to in vitro (Figure 4E, spot \#2). The modest decrease in activity, although not completely abolished, of heat shock $70 \mathrm{kDa}$ protein 5 after proteome extraction (Figure 4E, spot \#2) suggests a potentially more important role for this protein during HCV replication. These observations further outline the benefits of in situ profiling of proteins in their native cellular environment to obtain their accurate activity in presence of their cellular endogenous inhibitors/activators.

To examine if the fluorescence intensity difference observed during HCV replication could solely be attributed to differential enzymatic activity or could reflect differences in gene expression, the expression levels of five protein candidates identified by non-directed ABPP during $\mathrm{HCV}$ replication were analyzed by western blotting (Figure 5B). Both AHSG and ETFA differential activity levels (Figure 4F) correlated with protein level variations (Figure 5B) between naïve Huh-7 cells and those stably replicating HCV thus suggesting that the expression level of these genes is altered in Huh-7 stably replicating $\mathrm{HCV}$. The absence of any differential expression levels in the three remaining candidates (HSP70, PDIA1 and NUDC) could be explained by the fact that these enzymes display a differential activity during $\mathrm{HCV}$ replication, while having unchanged protein levels. Posttranslational modifications or the HCV-mediated modulation of endogenous inhibitors/activators or subcellular localization could explain this observation.

Some PS4三 identified candidates obtained from Huh-7 cells have been shown to be implicated in $\mathrm{HCV}$ or in HCV-related liver complications. For example, heat shock $70 \mathrm{kDa}$ protein 8 (HSP70A8 or HSP70 cognate) was recently shown to associate with HCV core, E2 protein, and viral particles around lipid droplets (LDs) to influence viral release and the abundance of cellular LDs [44]. We recently showed LDs to be highly abundant in Huh-7 cells with high levels of HCV pFK-I389neo/NS33'/5.1 replication (unpublished observation), which could explain the higher HSP70A8 activity (Figure 4F, spot \#3) resulting in more abundant LD and HSP70A8 aggregates [44]. Furthermore, the identified HSP70 proteins 5,8 and 9 , along with aldehyde dehydrogenase 1 , vimentin, cytokine-induced protein $29 \mathrm{kDa}$, and electron transfer flavoprotein alpha (ETFA), are known markers and proteins of interest in $\mathrm{HCV}$-associated hepatocellular carcinoma, cirrhosis and cellular interferon response [45-52].
The association of protein disulfide isomerase A1 and A4 activity (Figure 4, spots 1 and 6) with HCV replication levels was also observed with a novel origamicin probe [39], which reinforces the fact that these enzymes might catalyze cysteine oxidation and disulfide bond isomerization of $\mathrm{HCV}$ proteins, also known to be essential for the infectivity of other viruses (e.g. HIV) [53]. Another PS4 $\equiv$ target, alpha 2-HS-glycoprotein (AHSG), was found to associate with the 3'-untranslated region of the HCV genome, potentially regulating HCV replication [54]. The PS4三 profiling, in addition, allowed us to observe an increased activity of this protein, which could be mediated by HCV replication in Huh-7 cells (Figure 4, spot 7), suggesting a synergistic effect. Similarly, ETFA, involved in the beta-oxidation of fatty acids and the subsequent transfer of their electrons to the electron transport chain of the inner mitochondrial membrane, demonstrated a decreased activity during HCV replication (Figure 4, spot 19). Hepatitis C virus had been shown to inhibit mitochondrial electron transport and to increase reactive oxygen species (ROS) in vitro and in vivo [55], which correlates with the observed PS4 $\equiv$ labeling decrease of ETFA. Furthermore, as this enzyme is part of the fatty acid catabolism (i.e. beta-oxidation), its decreased activity during HCV replication could constitute an additional contributing factor to abundant Huh-7 lipid accumulation and potentially be a cause in HCV-mediated steatosis. To the best of our knowledge, the remaining differentially active proteins identified by PS4 $=$ during HCV replication, such as protein disulfide isomerase A5 and nuclear distribution gene $\mathrm{C}$ homolog, have not been studied so far in context with $\mathrm{HCV}$ thus making the PS4 $\equiv$ non-directed probe an important tool in identifying novel host-pathogen interactions. Further characterization of these enzymes will be required to confirm their differential activities and reveal their potential roles during HCV replication and infectivity.

\section{Conclusions}

In situ ABPP using a PS4三 probe identified 13 novel targets in Huh-7 cells replicating HCV RNA. Some, like HSP70A8, have a known importance in HCV propagation [44]. Six additional PS4” protein targets were previously identified in Huh-7 cells with a directed amino acid coupled quinolimine methide probe in vitro [19] validating this study's findings and methodology. Three novel potentially important host protein activity changes in the presence of replicating $\mathrm{HCV}$ involved proteins ETFA, protein disulfide isomerase A5, and nuclear distribution gene $\mathrm{C}$ homolog. These findings suggest that using both combinatorial and directed methods, either separately or in combination, can accelerate the discovery of protein activities associated with pathogenic states 
during HCV replication and infection. Collectively, these results highlight that in situ ABPP facilitates the probing of activity-based protein profiles that are predominantly or exclusively labeled in living cells. Furthermore, the strategy allows for the rapid identification of differentially active enzymes during HCV replication.

\section{Methods}

Chemical synthesis of PS4 $\equiv$ probe, $\mathrm{RhN}_{3}$, and TBTA ligand Synthesis of the PS4 $\equiv$ probe, $\mathrm{RhN}_{3}$, and tris-(benzyltriazoylmethyl) amine (TBTA) ligand were performed as described previously $[28,56]$.

\section{Tissue culture and reagents}

The human hepatoma cell line Huh-7 was grown in monolayers with DMEM medium supplemented with $100 \mathrm{nM}$ nonessential amino acids, $50 \mathrm{U} / \mathrm{mL}$ penicillin, $50 \mu \mathrm{g} / \mathrm{mL}$ streptomycin, and 10\% FBS (CANSERA, Rexdale, $\mathrm{ON})$. The Huh-7 cells stably expressing the subgenomic replicons (Figure 1A) (genotype 1B, con 1 ) (passage number between 40 and 50) were maintained in the same culture medium supplemented with $250 \mu \mathrm{g} /$ mL G418 Geneticin (GIBCO-BRL, Burlington, ON). The pFK-I389neo/NS3-3'/5.1 subgenomic replicon (Figure 1A) was kindly provided by Ralf Bartenschlager (Institute of Hygiene, University of Heidelberg, Germany).

\section{Active proteome extraction and in vitro activity based profiling}

Subconfluent cells (80-90\%) were washed and pooled with ice-cold $10 \mathrm{mM}$ sodium phosphate buffer, $\mathrm{pH} 7$. The cells were then subjected to Dounce-homogenization at $30 \%$ power (T8 Ika-Werke homogenizer, GMBH, Staufen, Germany) and sonicated (20 pulses, 50\% duty cycle, Sonifier 250, Branson Ultrasonic, Danbury, CT) in ice-cold sodium phosphate buffer supplemented with $1 \%$ Triton X-100. The crude proteome extract was cleared by ultra centrifugation at $100,000 \mathrm{~g}, 4^{\circ} \mathrm{C}$ for $45 \mathrm{~min}$, quantified with the BCA protein assay (Pierce, Rockford, IL) and diluted with sodium phosphate buffer to a final protein concentration of $1 \mathrm{mg} / \mathrm{mL}$. The in vitro active proteome labeling conditions were optimized as follows (Figure 2A): the proteome extract $(1 \mathrm{mg} / \mathrm{mL}$ in sodium phosphate buffer) was incubated in the dark with $20 \mu \mathrm{M}$ of PS4 $\equiv$ probe (from a $100 \mathrm{mM}$ stock in dimethyl sulfoxide (DMSO), final DMSO concentration of $0.02 \%$ ) for $1 \mathrm{~h}$ at $37^{\circ} \mathrm{C}$ with occasional mixing. After one hour, the reaction was quenched by precipitating the proteome with acetone: five volumes of ice-cold acetone were added to the sample, then the samples were frozen at $-80^{\circ} \mathrm{C}$ for $30 \mathrm{~min}$ and subsequently centrifuged at 15,000 $\mathrm{g}, 4^{\circ} \mathrm{C}$ for $15 \mathrm{~min}$ to remove salts and unreacted probe.

\section{In situ PS4三 protein profiling in Huh-7 hepatoma cells}

The in situ active proteome labeling conditions were optimized (Figure 2B) to the following: the cell culture media of subconfluent cells (80-90\%) was replaced with fresh media containing $100 \mu \mathrm{M}$ PS4 $\equiv$ probe (from a 100 $\mathrm{mM}$ stock in DMSO, final DMSO concentration of $0.1 \%$ ) for $1 \mathrm{hr}, 37^{\circ} \mathrm{C}, 5 \% \mathrm{CO} 2$ in a cell culture incubator to allow for cellular uptake and proteome labeling. The cells were subsequently washed twice with ice-cold 10 $\mathrm{mM}$ sodium phosphate buffer, $\mathrm{pH} 7$, and the proteome was harvested by Dounce-homogenization and sonication as described above.

\section{Bioorthogonal conjugation to $\mathrm{RhN}_{3}$ via cycloaddition reaction}

In vitro or in situ PS4三 labeled proteomes precipitated with acetone were resuspended in $200 \mu \mathrm{L}$ distilled water. Cycloaddition reagents were added sequentially: $200 \mu \mathrm{M} \mathrm{RhN} \mathrm{N}_{3}$ (2.6 mM stock in DMSO), $2 \mathrm{mM}$ sodium ascorbate (26 mM stock in water), and $200 \mu \mathrm{M}$ TBTA ligand (2.6 mM stock in 1:4 DMSO:t-butanol). Prior to addition of the copper catalyst, the reaction mixture was vortexed, and $2 \mathrm{mM} \mathrm{CuSO}_{4} .5 \mathrm{H}_{2} \mathrm{O}(26 \mathrm{mM}$ stock in water) was added. Samples were mixed and incubated at $25^{\circ} \mathrm{C}$ for 1 hour in the dark at room temperature. The reaction was quenched by acetone precipitation as described above.

\section{D analysis of labeled proteomes}

Precipitated protein pellets $(200 \mu \mathrm{g})$ were resuspended in $125 \mu \mathrm{l}$ of isoelectric focusing (IEF) buffer (7 M Urea, $2 \mathrm{M}$ thiourea, 4\% CHAPS, 1\% DTT) containing $0.2 \%$ Ampholytes pH 3-10 (biolytes, Bio-Rad, Hercules, CA). IPG strips pH 3-10 NL, 7 cm (Bio-Rad) were passively rehydrated with the resuspended proteomes for $16 \mathrm{~h}$. The rehydrated protein IPG strips were then submitted to isoelectric focusing using the Protean IEF Cell (BioRad) with the following conditions: $200 \mathrm{~V}$ rapid ramp for $30 \mathrm{~min}, 500 \mathrm{~V}$ rapid ramp for $30 \mathrm{~min}, 2 \mathrm{~h}$ linear ramp to $6,500 \mathrm{~V}$, and $2 \mathrm{~h}$ focusing (rapid ramp) at 6,500 $\mathrm{V}$. The accumulated voltage-hour $(\mathrm{VH})$ felt between a range of 12,000 - 17,500 VH.

Prior to SDS-PAGE separation, proteins immobilized on the IPG strips were reduced (1\% DTT) and alkylated (4\% iodoacetamide) in SDS equilibration buffer (6 M urea, 30\% glycerol, $2 \% \mathrm{SDS}, 50 \mathrm{mM}$ tris- $\mathrm{HCl}, \mathrm{pH} 8.8)$. The SDSPAGE separation was performed on a $10 \%$ gel $(1.5 \mathrm{~mm}$ thickness) at constant $150 \mathrm{~V}$ per gel. The gels were then scanned for fluorescence using the Typhoon 9410 (GE Healthcare, Piscataway, NJ) and were subsequently incubated overnight in fixing solution (50\% v/v Ethanol, 5\% v/ $\mathrm{v}$ acetic acid). Finally, gels were stained with silver nitrate and scanned using the Fluor-S imager (Bio-Rad) in order to visualize the entire cellular proteome. 


\section{Identification of labeled protein candidates}

The fluorescent gel image was aligned with the silver stained gel image to locate the labeled protein spots. Protein candidates displaying heat-sensitive activity were selected as specific targets, while candidates showing heat-insensitive reactivity were considered as non-specific targets. The selected spots were manually excised under a laminar flow hood. Gels spots were destained with potassium ferricyanide solution $(15 \mathrm{mM}$ potassium ferricyanide, $50 \mathrm{mM}$ sodium thiosulfate), rinsed three times with water, and then shrunk with acetonitrile. The gel pieces were reswelled with $20 \mu \mathrm{l}$ of trypsin solution $(0.01 \mu \mathrm{g} / \mu \mathrm{l}$ in $50 \mathrm{mM}$ ammonium bicarbonate $)$ and incubated overnight at $37^{\circ} \mathrm{C}$.

Peptides were identified by LC-MS/MS on a LTQ XL (Thermo) mass spectrometer. The LTQ XL mass spectrometer (Thermo) was coupled to a MDLC chromatography system (GE Healthcare). The samples were first injected onto a $0.3 \times 5 \mathrm{~mm} \mathrm{C18} \mathrm{micro} \mathrm{pre-column} \mathrm{car-}$ tridge (Dionex/LC Packings) to remove salts and other soluble contaminants. Samples were then separated on a $5 \mathrm{~cm} \times 75 \mu \mathrm{m}$ BioBasic C18, $5 \mu \mathrm{m}$ particle, PicoFrit column (New Objective) with a flow rate of $\sim 300 \mathrm{~nL} /$ minute using a 30 minute gradient: $0-30 \%$ acetonitrile/ $0.1 \%$ formic acid over 14 minutes, $30-50 \%$ acetonitrile $/ 0.1 \%$ formic acid over 14 minutes, $50-90 \%$ acetonitrile/ $0.1 \%$ formic acid over 2 minutes. MS and MS/MS data were collected in enhanced profile and normal centroid mode (scan rate: 8,000 amu/sec, scan range: 400-1,600), respectively. MS/MS was performed on the three most abundant multiple-charged peaks for each MS scan.

Peak lists were generated using the default parameters by Extract-MSN in BioWorksBrowser 3.2 (ThermoFisher). LC-MS/MS spectra were searched against the National Centre for Biotechnology Information non-redundant database (October 16, 2006; 2,879,860 sequence entries; 1,012,985,077 residues) using Mascot daemon version 2.0 (Matrix Science, London, UK). Search parameters used for queries were trypsin cleavage, $\leq 1$ missed cleavages, \pm 1.5 Da peptide tolerance, $\pm 1.2-\mathrm{Da}$ MS/MS tolerance, with no fixed modifications and the following variable modifications: carbamidomethyl (Cys), oxidation (Met). The results were then evaluated manually: protein identification required a MASCOT score above 50 , a corresponding $\mathrm{pI}$ and mass according to their position after 2D gel electrophoresis, as well as being identified in at least three independent experiments.

\section{Northern analysis}

Total RNA from subconfluent cells was isolated using the RNeasy extraction kit (Qiagen) and $1 \mu \mathrm{g}$ was used to detect HCV replicon RNA and $\beta$-actin mRNA. Biotinylated negative sense probes complementary to $\mathrm{HCV}$ genome region $6648-7770$ bp (NS5b) and $\beta$-actin
(GenBank accession numbers AJ242654 and X00351, respectively) were synthesized using the MEGAscript T7 kit (Ambion, Foster City, CA), biotin-11-UTP and biotin-11-CTP (PerkinElmer, Boston, MA) following the supplier's protocol. Northern blotting and hybridization were performed using the NorthernMax kit (Ambion) and Hybond XL nylon membranes (Amersham Biosciences, Piscataway, NJ). The bound riboprobes were detected with the Chemiluminescent Nucleic Acid Detection Module (Pierce, Rockford, IL).

\section{Western immunoblotting}

Proteomes $(40 \mu \mathrm{g}$ protein) were resuspended in SDS loading buffer, resolved by SDS-PAGE under reducing conditions ( $10 \%$ resolving gel), and transferred onto Hybond-P PVDF membrane (Amersham Biosciences). Thereafter, the membrane was blocked for $1 \mathrm{~h}$ in $5 \%$ dried skim milk in Tris-buffered saline (TBS) with 0.05\% Tween-20. Human HSP70, PDIA1, AHSG, NUDC, ETFA, HCV NS5a, HCV NS3, and human $\beta$ tubulin were targeted with: a mouse monoclonal antiHSP70 (1000-fold dilution in TBS-Tween; Abcam, Cambridge, UK), a mouse monoclonal anti-PDIA1 (5000-fold dilution in TBS-Tween, Abcam), a mouse monoclonal anti-human fetuin A/AHSG (200-fold dilution in TBSTween, R\&D systems, Minneapolis, MN), a mouse monoclonal anti-NUDC (1000-fold dilution in TBSTween; Santa Cruz Biotechnology, Santa Cruz, CA), a rabbit polyclonal anti-ETFA (500-fold dilution in TBSTween; ProteinTech Group, Chicago, IL), a mouse monoclonal anti-NS5a $(0.2 \mu \mathrm{g} / \mathrm{mL}$ in TBS-Tween; ViroStat, Portland, ME), a mouse monoclonal anti-NS3 (0.2 $\mu \mathrm{g} / \mathrm{mL}$ in TBS-Tween; ViroStat), and a mouse monoclonal anti- $\beta$-tubulin $(3.5 \mu \mathrm{g} / \mathrm{mL}$ in TBS-Tween; Sigma), respectively. After extensive washing, the membrane was incubated for $1 \mathrm{~h}$ with the donkey anti-rabbit IgG horseradish peroxidase (HRP)-conjugated antibody $(0.26 \mu \mathrm{g} /$ $\mathrm{mL}$ in TBS-Tween) or with the goat anti-mouse HRPconjugated antibody $(0.8 \mu \mathrm{g} / \mathrm{mL}$ in TBS-Tween; Jackson ImmunoResearch, West Grove, PA). Antigens were detected using enhanced chemiluminescence (ECL Western Blotting Detection Reagents; Amersham Biosciences).

\section{Statistical analysis}

Individual experiments in this study were performed at least in triplicate in order to confirm the reproducibility of the results. Values are represented as means \pm standard deviations. The statistical significance of differences between two or more means was evaluated by using analysis of variance (ANOVA); P values of less than 0.05 (indicated by asterisks) were considered to be statistically significant. 


\section{Abbreviations}

2D-GE: 2D-gel electrophoresis; ABPP: activity-based protein profiling; ANOVA: analysis of variance; AHSG: alpha 2-HS-glycoprotein; Cys: carbamidomethyl; DMSO: dimethyl sulfoxide; ETFA: electron transfer flavoprotein alpha polypeptide; HCV: hepatitis C virus; HSP70: Heat shock protein 70 kDa; IEF: isoelectric focusing; LD: lipid droplet; MudPIT: multidimensional protein identification technology; NS: non-structural; nu: nucleophile; NUDC: nuclear distribution gene C homolog; PDI: protein disulfide isomerise; PS4三: phenyl sulfonate ester; $\mathrm{RhN}_{3}$ : rhodamine azide; ROS: reactive oxygen species; TBTA: tris-(benzyltriazoylmethyl) amine; VH: voltage-hour.

\section{Acknowledgements}

We thank Dr. John Kelly for mass spectrometry analyses. This work was supported by the Canadian Liver Foundation, the Canadian Institutes for Health Research and NRC's Genomics and Health Initiative

\section{Author details}

'Steacie Institute for Molecular Sciences, National Research Council Canada, Ottawa, Ontario, K1A OR6, Canada. ${ }^{2}$ Department of Biochemistry, Microbiology and Immunology, University of Ottawa, Ottawa, Ontario, K1N $6 \mathrm{~N} 5$, Canada. ${ }^{3}$ Department of Chemistry, University of Ottawa, Ottawa, Ontario, K1N 6N5, Canada.

\section{Authors' contributions}

RS carried out the activity-based proteome analysis and the acquisition of the proteomic sequences. DRB participated in the design and in the coordination of the study, carried the analysis and interpretation of the proteomic sequences, and drafted the manuscript. CSM synthesized the phenyl sulfonate ester probe and reporter tag azide. JPP conceived, participated in the design and in the coordination of the study, and drafted the manuscript. All authors read and approved the final manuscript.

\section{Competing interests}

The authors declare that they have no competing interests.

Received: 8 October 2009

Accepted: 4 February 2010 Published: 4 February 2010

\section{References}

1. Lavanchy D: The global burden of hepatitis C. Liver Int 2009, 29(Suppl 1):74-81.

2. Lindenbach $B D$, Rice $C M$ : Unravelling hepatitis $C$ virus replication from genome to function. Nature 2005, 436:933-938.

3. Ploss A, Evans MJ, Gaysinskaya VA, Panis M, You H, de Jong YP, Rice CM Human occludin is a hepatitis $C$ virus entry factor required for infection of mouse cells. Nature 2009, 457:882-886.

4. Okamoto K, Mori Y, Komoda Y, Okamoto T, Okochi M, Takeda M, Suzuki T, Moriishi K, Matsuura Y: Intramembrane processing by signal peptide peptidase regulates the membrane localization of hepatitis $C$ virus core protein and viral propagation. J Virol 2008, 82:8349-8361.

5. Goffard A, Callens N, Bartosch B, Wychowski C, Cosset FL, Montpellier C, Dubuisson J: Role of $\mathrm{N}$-linked glycans in the functions of hepatitis $\mathrm{C}$ virus envelope glycoproteins. J Virol 2005, 79:8400-8409.

6. Reed KE, Xu J, Rice CM: Phosphorylation of the hepatitis C virus NS5A protein in vitro and in vivo: properties of the NS5A-associated kinase. $J$ Virol 1997, 71:7187-7197.

7. Wang C, Gale M Jr, Keller BC, Huang H, Brown MS, Goldstein JL, Ye J: Identification of FBL2 as a geranylgeranylated cellular protein required for hepatitis C virus RNA replication. Mol Cell 2005, 18:425-434.

8. Jopling CL, Yi M, Lancaster AM, Lemon SM, Sarnow P: Modulation of hepatitis C virus RNA abundance by a liver-specific MicroRNA. Science 2005, 309:1577-1581.

9. Jopling CL, Schutz S, Sarnow P: Position-dependent function for a tandem microRNA miR-122-binding site located in the hepatitis $C$ virus RNA genome. Cell Host Microbe 2008, 4:77-85.

10. Su Al, Pezacki JP, Wodicka L, Brideau AD, Supekova L, Thimme R, Wieland S, Bukh J, Purcell RH, Schultz PG, Chisari FV: Genomic analysis of the host response to hepatitis C virus infection. Proc Natl Acad Sci USA 2002, 99:15669-15674.
11. Fang C, Yi Z, Liu F, Lan S, Wang J, Lu H, Yang P, Yuan Z: Proteome analysis of human liver carcinoma Huh7 cells harboring hepatitis $C$ virus subgenomic replicon. Proteomics 2006, 6:519-527.

12. Evans MJ, Cravatt BF: Mechanism-based profiling of enzyme families. Chem Rev 2006, 106:3279-3301.

13. Kocks C, Maehr R, Overkleeft HS, Wang EW, lyer LK, Lennon-Dumenil AM, Ploegh $\mathrm{HL}$, Kessler BM: Functional proteomics of the active cysteine protease content in Drosophila S2 cells. Mol Cell Proteomics 2003, 2:1188-1197.

14. Kaschani F, Gu C, Niessen S, Hoover H, Cravatt BF, Hoorn van der RA: Diversity of serine hydrolase activities of unchallenged and botrytisinfected Arabidopsis thaliana. Mol Cell Proteomics 2009, 8:1082-1093.

15. Barglow KT, Cravatt BF: Activity-based protein profiling for the functional annotation of enzymes. Nat Methods 2007, 4:822-827.

16. Liu Y, Patricelli MP, Cravatt BF: Activity-based protein profiling: the serine hydrolases. Proc Natl Acad Sci USA 1999, 96:14694-14699.

17. Kato D, Boatright KM, Berger AB, Nazif T, Blum G, Ryan C, Chehade KAH, Salvesen GS, Bogyo M: Activity-based probes that target diverse cysteine protease families. Nat Chem Biol 2005, 1:33-38.

18. Zhu Q, Girish A, Chattopadhaya S, Yao SQ: Developing novel activitybased fluorescent probes that target different classes of proteases. Chem Commun 2004, 7:1512-1513.

19. Blais DR, Brûlotte M, Qian Y, Bélanger S, Yao SQ, Pezacki JP: Activity-based proteome profiling of hepatoma cells during hepatitis $C$ virus replication using protease substrate probes. J Proteome Res 2009, 9:912-923.

20. Adam GC, Cravatt BF, Sorensen EJ: Profiling the specific reactivity of the proteome with non-directed activity-based probes. Chem Biol 2001, 8:81-95.

21. Adam GC, Sorensen EJ, Cravatt BF: Proteomic profiling of mechanistically distinct enzyme classes using a common chemotype. Nat Biotechnol 2002, 20:805-809.

22. Barglow KT, Cravatt BF: Discovering disease-associated enzymes by proteome reactivity profiling. Chem Biol 2004, 11:1523-1531.

23. Evans MJ, Saghatelian A, Sorensen EJ, Cravatt BF: Target discovery in small-molecule cell-based screens by in situ proteome reactivity profiling. Nat Biotechnol 2005, 23:1303-1307.

24. Jessani N, Cravatt BF: The development and application of methods for activity-based protein profiling. Curr Opin Chem Biol 2004, 8:54-59.

25. Speers AE, Cravatt BF: Chemical strategies for activity-based proteomics. Chembiochem 2004, 5:41-47.

26. Rakic B, Sagan SM, Noestheden M, Belanger S, Nan XL, Evans CL, Xie XS, Pezacki JP: Peroxisome proliferator-activated receptor alpha antagonism inhibits hepatitis C virus replication. Chem Biol 2006, 13:23-30.

27. Adam GC, Burbaum J, Kozarich JW, Patricelli MP, Cravatt BF: Mapping enzyme active sites in complex proteomes. J Am Chem Soc 2004, 126:1363-1368.

28. Speers $A E$, Cravatt $B F$ : Profiling enzyme activities in vivo using click chemistry methods. Chem Biol 2004, 11:535-546.

29. Kobe B, Kemp BE: Active site-directed protein regulation. Nature 1999, 402:373-376.

30. Futai $M$, Omote $H$, Sambongi $Y$, Wada $Y$ : Synthase $(H(+)$ ATPase): coupling between catalysis, mechanical work, and proton translocation. Biochim Biophys Acta 2000, 1458:276-288.

31. Adam GC, Sorensen EJ, Cravatt BF: Trifunctional chemical probes for the consolidated detection and identification of enzyme activities from complex proteomes. Mol Cell Proteomics 2002, 1:828-835.

32. Speers $A E$, adam $G C$, cravatt $B F$ : Activity-based protein profiling in vivo using a copper(1)-catalyzed azide-alkyne [3+2] cycloaddition. J Am Chem Soc 2003, 125:4686-4687.

33. Puig A, Lyles MM, Noiva R, Gilbert HF: The role of the thiol/disulfide centers and peptide binding site in the chaperone and anti-chaperone activities of protein disulfide isomerase. J Biol Chem 1994, 269:19128-19135.

34. Hurley TD, Weiner $\mathrm{H}$ : Evaluation of the roles of the conserved residues of aldehyde dehydrogenase. Adv Exp Med Biol 1999, 463:45-52.

35. Dey S, Burton RL, Grant GA, Sacchettini JC: Structural analysis of substrate and effector binding in Mycobacterium tuberculosis D-3phosphoglycerate dehydrogenase. Biochemistry 2008, 47:8271-8282.

36. Erion MD, Takabayashi K, Smith HB, Kessi J, Wagner S, Honger S, Shames SL, Ealick SE: Purine nucleoside phosphorylase. 1. Structure-function studies. Biochemistry 1997, 36:11725-11734. 
37. Lohmann V, Korner F, Koch J, Herian U, Theilmann L, Bartenschlager R: Replication of subgenomic hepatitis $C$ virus RNAs in a hepatoma cell line. Science 1999, 285:110-113.

38. Supekova L, Supek F, Lee J, Chen S, Gray N, Pezacki JP, Schlapbach A, Schultz PG: Identification of human kinases involved in hepatitis $C$ virus replication by small interference RNA library screening. J Biol Chem 2008, 283:29-36.

39. Rakic B, Clarke J, Tremblay TL, Taylor J, Schreiber K, Nelson KM, Abrams SR, Pezacki JP: A small-molecule probe for hepatitis $C$ virus replication that blocks protein folding. Chem Biol 2006, 13:1051-1060.

40. Rakic B, Brulotte M, Rouleau Y, Belanger S, Pezacki JP: Bleomycin is a potent small-molecule inhibitor of hepatitis $C$ virus replication. Chembiochem 2006, 7:1330-1333.

41. Tonary AM, Pezacki JP: Simultaneous quantitative measurement of luciferase reporter activity and cell number in two- and threedimensional cultures of hepatitis C virus replicons. Anal Biochem 2006 350:239-248.

42. Sagan SM, Rouleau Y, Leggiadro C, Supekova L, Schultz PG, Su Al, Pezacki JP: The influence of cholesterol and lipid metabolism on host cell structure and hepatitis C virus replication. Biochem Cell Biol 2006, 84:67-79.

43. Steinkuhler C, Biasiol G, Brunetti M, Urbani A, Koch U, Cortese R, Pessi A, De Francesco R: Product inhibition of the hepatitis C virus NS3 protease. Biochemistry 1998, 37:8899-8905.

44. Parent R, Qu X, Petit MA, Beretta L: The heat shock cognate protein 70 is associated with hepatitis $C$ virus particles and modulates virus infectivity. Hepatology 2009, 49:1798-1809.

45. Choong ML, Tan LK, Lo SL, Ren EC, Ou K, Ong SE, Liang RC, Seow TK, Chung MC: An integrated approach in the discovery and characterization of a novel nuclear protein over-expressed in liver and pancreatic tumors. FEBS Lett 2001, 496:109-116.

46. Jacobs JM, Diamond DL, Chan EY, Gritsenko MA, Qian W, Stastna M, Baas T, Camp DG, Carithers RL Jr, Smith RD, Katze MG: Proteome analysis of liver cells expressing a full-length hepatitis $C$ virus (HCV) replicon and biopsy specimens of posttransplantation liver from HCV-infected patients. J Virol 2005, 79:7558-7569.

47. Teramoto R, Minagawa H, Honda M, Miyazaki K, Tabuse Y, Kamijo K, Ueda T, Kaneko S: Protein expression profile characteristic to hepatocellular carcinoma revealed by 2D-DIGE with supervised learning. Biochim Biophys Acta 2008, 1784:764-772.

48. Tsutsumi T, Matsuda M, Aizaki H, Moriya K, Miyoshi H, Fujie H, Shintani Y, Yotsuyanagi H, Miyamura T, Suzuki T, Koike K: Proteomics analysis of mitochondrial proteins reveals overexpression of a mitochondrial protein chaperon, prohibitin, in cells expressing hepatitis $C$ virus core protein. Hepatology 2009, 50:378-386

49. Nitahara-Kasahara Y, Fukasawa M, Shinkai-Ouchi F, Sato S, Suzuki T, Murakami K, Wakita T, Hanada K, Miyamura T, Nishijima M: Cellular vimentin content regulates the protein level of hepatitis $C$ virus core protein and the hepatitis $C$ virus production in cultured cells. Virology 2009, 383:319-327.

50. Li Q, Brass AL, Ng A, Hu Z, Xavier RJ, Liang TJ, Elledge SJ: A genome-wide genetic screen for host factors required for hepatitis $C$ virus propagation. Proc Natl Acad Sci USA 2009, 106:16410-16415.

51. Xun M, Zhao SH, Cao CX, Song J, Shao MM, Chu YL: Proteomic analysis of HuH-7 cells harboring in vitro-transcribed full-length hepatitis $C$ virus $1 \mathrm{~b}$ RNA. Acta Pharmacol Sin 2008, 29:720-727.

52. Pacheco A, Reigadas S, Martinez-Salas E: Riboproteomic analysis of polypeptides interacting with the internal ribosome-entry site element of foot-and-mouth disease viral RNA. Proteomics 2008, 8:4782-4790.

53. Ryser HJ, Levy EM, Mandel R, DiSciullo GJ: Inhibition of human immunodeficiency virus infection by agents that interfere with thioldisulfide interchange upon virus-receptor interaction. Proc Natl Acad SCi USA 1994, 91:4559-4563.

54. Harris D, Zhang Z, Chaubey B, Pandey VN: Identification of cellular factors associated with the $3^{\prime}$-nontranslated region of the hepatitis $C$ virus genome. Mol Cell Proteomics 2006, 5:1006-1018.

55. Korenaga M, Wang T, Li Y, Showalter LA, Chan T, Sun J, Weinman SA: Hepatitis $C$ virus core protein inhibits mitochondrial electron transport and increases reactive oxygen species (ROS) production. $J$ Biol Chem 2005, 280:37481-37488.
56. Chan TR, Hilgraf R, Sharpless KB, Fokin W: Polytriazoles as copper(I)stabilizing ligands in catalysis. Org Lett 2004, 6:2853-2855.

doi:10.1186/1477-5956-8-5

Cite this article as: Singaravelu et al:: Activity-based protein profiling of the hepatitis

$C$ virus replication in Huh-7 hepatoma cells

using a non-directed active site probe. Proteome Science 2010 8:5.

\section{Submit your next manuscript to BioMed Central and take full advantage of:}

- Convenient online submission

- Thorough peer review

- No space constraints or color figure charges

- Immediate publication on acceptance

- Inclusion in PubMed, CAS, Scopus and Google Scholar

- Research which is freely available for redistribution

Submit your manuscript at www.biomedcentral.com/submit
Ciomed Central 